\title{
A keystone predatory sea star in the intertidal zone is controlled by a higher-order predatory sea star in the subtidal zone
}

\author{
Carlos F. Gaymer ${ }^{1, *}$, John H. Himmelman ${ }^{2}$ \\ ${ }^{1}$ Departamento de Biología Marina and Centro de Estudios Avanzados en Zonas Áridas (CEAZA), \\ Universidad Católica del Norte, Larrondo 1281, Coquimbo, Chile \\ ${ }^{2}$ Département de Biologie, Université Laval, Quebec City, Quebec G0V 0A6, Canada
}

\begin{abstract}
The impact of keystone predators may be affected by physical conditions and interactions with other predators. We evaluated the impact of the sea star Meyenaster gelatinosus on another sea star, Heliaster helianthus, which was previously described as a keystone predator along the coast of central Chile. Field surveys showed that $H$. helianthus is a common prey of M. gelatinosus. $H$. helianthus occurred across the subtidal zone at locations with few $M$. gelatinosus, but was largely restricted to the intertidal and upper-subtidal zones at locations where $M$. gelatinosus was abundant. The proportion of $H$. helianthus feeding decreased with increasing $M$. gelatinosus abundance, and $H$. helianthus with autotomized arms, mainly the result of sublethal attacks by M. gelatinosus, increased with increasing $M$. gelatinosus abundance. Additions of $M$. gelatinosus to a sediment bottom area where $H$. helianthus was actively feeding on the gastropod Turritella cingulata provoked (1) reduced feeding and (2) a strong escape response in which $H$. helianthus took the 'crown' position (arm tips raised) in about $40 \mathrm{~s}$ and then fled. T. cingulata is an abundant prey resource that is likely only available to $H$. helianthus when $M$. gelatinosus is rare. The predatory role of $H$. helianthus is greatly reduced when $M$. gelatinosus is common. Our observations suggest that M. gelatinosus, rather than $H$. helianthus or the whelk Concholepas concholepas, is the keystone predator in subtidal communities. Our study demonstrates that the role of a keystone predator (in our case $H$. helianthus in the intertidal zone) can change in an adjacent habitat (the subtidal zone) due to interactions with other predators.
\end{abstract}

KEY WORDS: Predator-prey interaction · Sublethal predation · Distribution · Autotomy $\cdot$ Sea star Ecological role $\cdot$ Keystone $\cdot$ Chile

\section{INTRODUCTION}

Predators strongly affect the ecology of their prey and in turn community structure. Their impact is not limited to reducing prey numbers (Sih et al. 1985), as predators can cause changes in prey morphology (Reimer \& Harms-Ringdahl 2001), size (Norberg \& Tedengren 1995), spatial distribution (Rochette \& Dill 2000, Esser et al. 2004, Yunger 2004), behavior (Lima \& Dill 1990, Reimer et al. 1995, Trussell et al. 2003, 2004) and the duration of vulnerable life stages (Dahl \& Peckarsky 2003). Predators usually affect the structure of the communities they inhabit, and keystone predators can control important species that occupy primary space on the sea bottom. This has been illustrated for killer whales in nearshore benthic communities (Estes et al. 1998) and sea star predators in intertidal communities (Paine 1974, Paine et al. 1985, Menge et al. 1994). However, the role of most keystone predators has only been documented for specific habitats. The keystone role of a predator may not extend to all habitats where the predator is found, as its impact may change with physical conditions and interactions with other predators (Power et al. 1996). For example, the 
role of the classic keystone predator Pisaster ochraceus in the northeastern North Pacific applies to exposed rocky intertidal habitats, but not to sheltered habitats (Menge et al. 1994).

Paine et al. (1985) reported that the sun star Heliaster helianthus is a keystone predator in intertidal communities along the coast of central Chile. Its foraging limits the lower limit of the mussel Perumytilus purpuratus, which tends to monopolize rocky surfaces when $H$. helianthus is absent. However, its importance as a predator may change in the subtidal zone. Viviani (1978) suggested that $H$. helianthus is limited to shallow rocky areas because these areas provide it with a refuge from Meyenaster gelatinosus, a voracious predatory sea star found from low tide level down to $\sim 25 \mathrm{~m}$ in depth. M. gelatinosus strongly selects echinoderm prey, such as $H$. helianthus and the black sea urchin Tetrapygus niger (Aburto 1999), and provokes strong escape responses from the sea urchin and several species of molluscs (Dayton et al. 1977, Serra et al. 1997, Ortiz et al. 2003, C. F. Gaymer unpubl. data). H. helianthus can represent $\sim 15 \%$ of the diet of M. gelatinosus in northern Chile (Viviani 1978). M. gelatinosus likely completely consumes small $H$. helianthus; however, interactions with large $H$. helianthus are usually not lethal, but can result in arm loss (as many as 9 arms in 1 attack; Viviani 1978). Non-lethal effects may cause indirect interactions that may lead to important changes in community structure. Trait-mediated indirect interactions have recently been reviewed for different systems and may drive trophic cascades (Abrams et al. 1996).

Our recent observations of subtidal communities in central and northern Chile show that Heliaster helianthus can occur throughout the rocky subtidal zone and suggest that its abundance and distribution is negatively related to the abundance of Meyenaster gelatinosus. Such changes in the distribution of $H$. helianthus should in turn affect its predatory role in different habitats. The present study evaluates the impact of M. gelatinosus on $H$. helianthus, specifically on its distribution, access to food, feeding activity and its importance as a predator in subtidal communities. We show that the role of a keystone predator in one habitat can be modified by interactions with a higherorder predator in an adjacent habitat.

\section{MATERIALS AND METHODS}

Study sites. We quantified the distribution and feeding of Heliaster helianthus and Meyenaster gelatinosus at 4 locations: Flamenco and Ramada, where both sea star species were common, and Bahía Cisnes and Obispito, where $H$. helianthus was common but
M. gelatinosus was rare. All 4 locations were within a $100 \mathrm{~km}$ section of coastline in central-northern Chile $\left(26^{\circ} 34^{\prime} 21.6^{\prime \prime} \mathrm{S}\right.$ to $\left.27^{\circ} 14^{\prime} 55^{\prime \prime} \mathrm{S}\right)$, were similar in respect to exposure to waves and supported similar potential prey. Also, at all locations the bottom was mainly a gently sloped bedrock platform which extended to about $7 \mathrm{~m}$ in depth, where a sediment slope began. At each location there was a narrow belt of the kelp Lessonia nigrescens down to $1 \mathrm{~m}$ in depth followed by sea urchin barrens, which extended to the end of the rocky zone. The barrens occasionally supported patches of the mussel Semimytilus algosus, the tunicate Pyura chilensis, the gastropods Tegula spp., Crepidula spp. and Calyptrea trochiformis, and barnacles. The sediment slope supported extremely high densities of the detritivorous gastropod Turritella cingulata (up to $\sim 4000$ ind. $\mathrm{m}^{-2}$ ).

Field sampling. At each location, we quantified depth, substratum type and prey availability along 5 transects that ran perpendicular to the shore, from the low tide level to several meters into the sediment bottom (ending at 7 to $11 \mathrm{~m}$ below lowest water of spring tides [LWST]). The transects were spaced at $20 \mathrm{~m}$ intervals along the shore. We examined $1 \mathrm{~m}^{2}$ quadrats placed at $1 \mathrm{~m}$ intervals, on alternating sides of each transect (the side of the first quadrat was chosen at random), and recorded (1) depth, (2) percentage cover of different substrata (sand, pebbles, cobbles, boulders and bedrock; as defined by Wentworth 1922) and (3) numbers of major prey items. Further, for each quadrat we recorded the number and radius (distance from the center of the disc to the end of the longest arm) of each Heliaster helianthus and Meyenaster gelatinosus, and noted when $H$. helianthus showed arm autotomy (loss of arms). We also recorded whether each sea star was feeding, and if so, identified and measured the size of the prey. The sampling at Flamenco, Ramada and Bahía Cisnes was done during winter 2003 and 2004, and during summer 2004 and 2005; the sampling at Obispito was done in winter 2003 and summer 2004. The quadrat data permitted us to calculate Yule's $V$ selectivity index (Kendall 1947), as an index of prey selection relative to availability (Pearre 1982). The coefficient ranges from -1 to +1 , with 0 indicating that prey are consumed according to availability.

As there were no marked differences in the densities of Heliaster helianthus and Meyenaster gelatinosus on different sampling dates at each study location, values were pooled for each sea star at each location. For each location, we applied a 1-way ANOVA to evaluate whether the size of $H$. helianthus varied with depth and a crossed 2-way ANOVA to test for differences in the density of the 2 sea star species (fixed factor) with depth (fixed factor) (all sampling dates pooled). The quadrats taken within each $2 \mathrm{~m}$ depth interval were 
used as replicates for these analyses. Data were logtransformed $(\ln (y+1))$ when necessary to obtain normality and homoscedasticity of the data. Normality was tested using the Shapiro-Wilk test (SAS Institute 1991) and homogeneity of variances using the Levene test (Snedecor \& Cochran 1989). When these assumptions were not met, the ANOVAs were applied to both the raw and rank-transformed data, as suggested by Conover (1980). The former was chosen for presentation when results were the same for the 2 analyses and the latter when they were not. A multiple pairwise comparison test (least-square means) was used to test for specific differences within a significant source of variation (SAS Institute 1991). We tested for differences in the proportion of $H$. helianthus feeding, and showing arm autotomy, using a generalized linear model with a binomial distribution and an incomplete factorial design (McCullagh \& Nelder 1989) and followed with multiple comparisons using Glimmix's macro (Littell et al. 1996).

To examine whether there was an association between the abundance of Heliaster helianthus and that of Meyenaster gelatinosus, we applied a correlation analysis to their densities observed in the 641 quadrats sampled over $2.5 \mathrm{yr}$. We further tested whether (1) the proportion of $H$. helianthus showing arm autotomy and (2) the proportion of $H$. helianthus that were feeding were correlated with the abundance of $M$. gelatinosus, and $t$-tests were used to evaluate whether Spearman rank correlation coefficients $\left(\mathrm{r}_{\mathrm{S}}\right)$ were significant (Steel \& Torrie 1980).

Effect of Meyenaster gelatinosus additions on Heliaster helianthus in the field. To study responses of $H$. helianthus to $M$. gelatinosus, we ran field experiments in 2004 on the sediment bottom at Bahía Cisnes. At this location $M$. gelatinosus was rare on the rocky bottom and absent on the deeper sediment slope. The experiments were performed in 13 circular areas measuring $3 \mathrm{~m}$ in diameter, each delineated by sticks that were driven into the sediment bottom along the circumference of the area. There were naturally ca. $8 \mathrm{H}$. helianthus in each circular area $\left(\sim 1.1\right.$ ind. $\left.\mathrm{m}^{-2}\right)$, and all were feeding on the gastropod Turritella cingulata, which was extremely abundant in this area. Just prior to each trial, we quantified the proportion of $H$. helianthus that were feeding (a humped position is taken when prey are being digested, Fig. 1). We started each trial by adding 4 large $M$. gelatinosus (15 to $18 \mathrm{~cm}$ radius) to the center of the circular area, without disturbing the $H$. helianthus naturally present in the area. This resulted in a M. gelatinosus density in the circular area equivalent to the maximal abundance observed at Flamenco and Ramada ( 0.6 ind. $\mathrm{m}^{-2}$ ). We then recorded the behavior and position of $H$. helianthus over time (at 5 to 10 min intervals), using digital chronometers and graduated plastic rods, until all $H$. helianthus had left the circular area (the end of the trial). We noted (1) when each $H$. helianthus left the circular area and (2) whether it was feeding as it left ( $H$. helianthus can feed as it moves). As moving sea stars lost their humped position, feeding was checked by turning sea stars over to see if the stomach was evaginated over a prey item. Seven trials were conducted in this way, and no M. gelatinosus were added to the remaining 6 areas that served as controls. During the course of these trials other sea stars observed near the experimental areas were removed.

We applied a crossed 2-way ANOVA to test for differences between control and Meyenaster gelatinosus addition areas (fixed factor) in the proportion of Heliaster helianthus that left the circular areas at different times (fixed factor). Data were arcsine-transformed when necessary to obtain normality and homoscedasticity of the data. Normality, homogeneity of variances and multiple comparisons were made as described in the previous section. Differences in percentage feeding were evaluated in the same way as proportion feeding in the transects.

During the above experiment, and on other occasions, we noted that Heliaster helianthus displayed a striking escape response when touched by Meyenaster gelatinosus. Thus, we ran trials while diving $(\mathrm{n}=43)$ to quantify this behavior. In each trial, we placed $1 \mathrm{arm}$ of a large $M$. gelatinosus on top of a feeding $H$. helianthus and then, using a chronometer, recorded the behaviors of the $H$. helianthus until it was no longer in contact with the M. gelatinosus. Different sea stars were used in each trial.

\section{RESULTS}

\section{Distribution and abundance of sea stars}

Heliaster helianthus showed 2 distinct distributional patterns with respect to depth. At Flamenco and Ramada, where Meyenaster gelatinosus was common, $H$. helianthus was restricted to the first $4 \mathrm{~m}$ in depth. This corresponded to the zone just below the belt of the kelp Lessonia nigrescens in the intertidal zone. Densities peaked at $\sim 0.7 \mathrm{~m}^{-2}$ at $1 \mathrm{~m}$ in depth, fell to $\sim 0.2 \mathrm{~m}^{-2}$ at $3 \mathrm{~m}$ and to $0 \mathrm{~m}^{-2}$ at $>4 \mathrm{~m}$ (Table 1, Fig. 2). The reduction in numbers of $H$. helianthus at $3 \mathrm{~m}$ coincided with the zone where the abundance of $M$. gelatinosus peaked $\left(\sim 0.5\right.$ ind $\left.\mathrm{m}^{-2}\right)$. In contrast, at Bahia Cisnes and Obispito, where M. gelatinosus densities were consistently low $\left(<0.1\right.$ ind. $\left.\mathrm{m}^{-2}\right), H$. helianthus occurred throughout the rocky subtidal zone and also extended well into the sediment bottom zone with densities of 0.7 to $1.3 \mathrm{~m}^{-2}$. Although $M$. gelatinosus densi- 

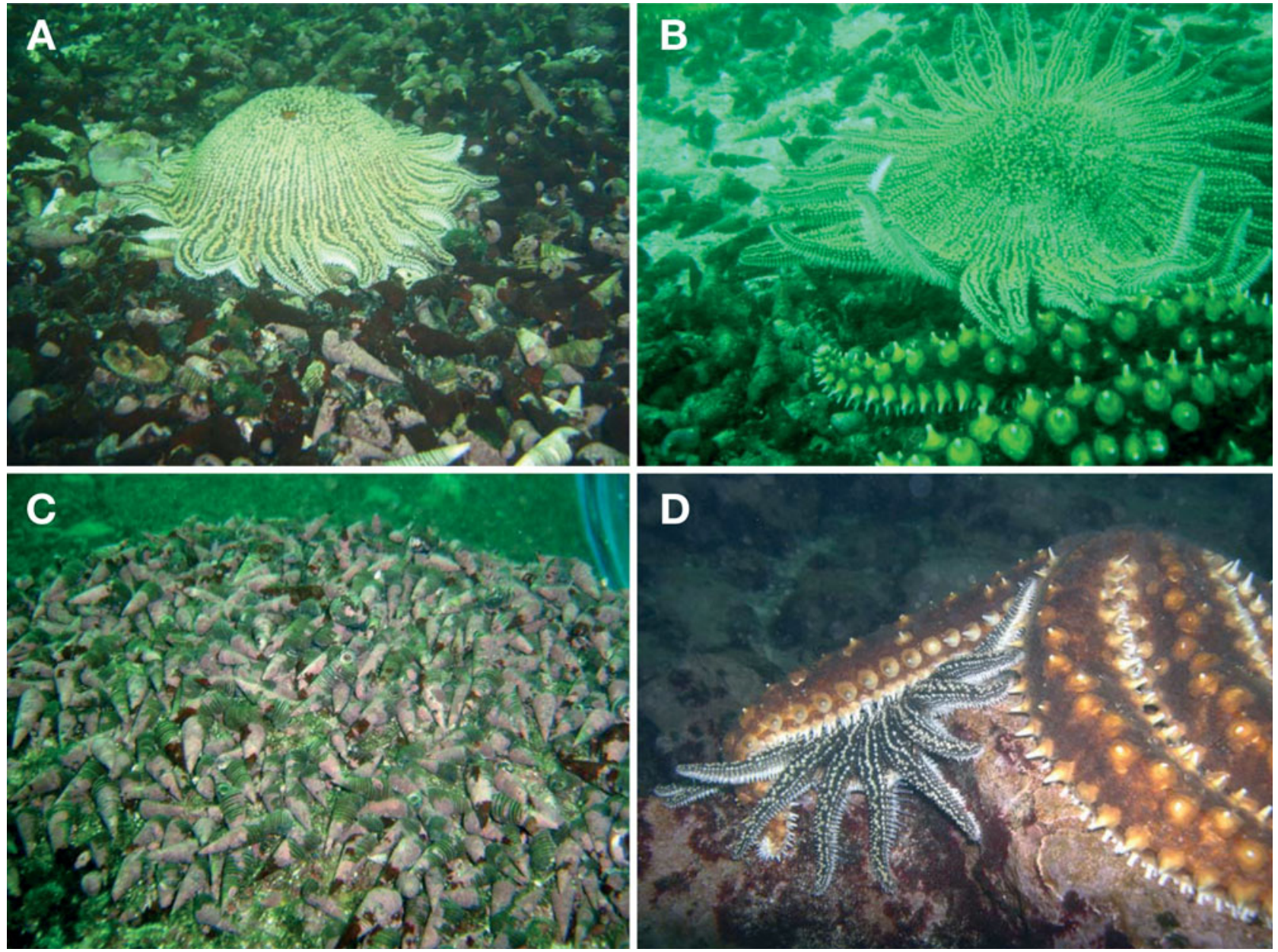

Fig. 1. Heliaster helianthus, Turritella cingulata and Meyenaster gelatinosus. (A) H. helianthus in humped position while feeding on the gastropod T. cingulata; (B) H. helianthus beginning to take on the 'crown' position (arm tips raised) in response to contact with its predator M. gelatinosus; (C) T. cingulata covering the sediment bottom at Bahía Cisnes; (D) M. gelatinosus capturing H. helianthus on a rocky slope. Note the large size and thick arms of $M$. gelatinosus in contrast to smaller and thinner body of $H$. helianthus

ties were low throughout the rocky zone at Bahia Cisnes and Obispito, we nevertheless observed decreases in the density of $H$. helianthus at the depths where the density of $M$. gelatinosus showed slight increases (Table 1, Fig. 2). In spite of the overall inverse abundance patterns for the 2 sea stars, the 2 species were not segregated at a small scale (the scale of our $1 \mathrm{~m}^{2}$ sampling quadrats) as no correlation was detected between density values for the 2 sea stars in the quadrats taken at any of the 4 locations (Flamenco, $\mathrm{r}_{\mathrm{S}}=0.08, \mathrm{p}=0.21 ;$ Ramada, $\mathrm{r}_{\mathrm{S}}=-0.02, \mathrm{p}=0.78 ;$ Bahía Cisnes, $\mathrm{r}_{\mathrm{S}}=0.06, \mathrm{p}=0.42$; Obispito $\mathrm{r}_{\mathrm{S}}=0.02, \mathrm{p}=0.87$ ).

The size of Heliaster helianthus at different depths also varied between the locations with high and low abundance of Meyenaster gelatinosus (Fig. 3). At Flamenco and Ramada, where M. gelatinosus was common, average size increased with depth, because smaller individuals ( 6 to $8 \mathrm{~cm}$ in radius) were restricted to the intertidal (Flamenco) or upper subtidal (Ramada) zones. In contrast, at Bahía Cisnes, where $M$. gelatinosus was rare, smaller $H$. helianthus were found on soft bottoms at greater depths and larger individuals $(\sim 20 \mathrm{~cm})$ at shallower depths. At Obispito, where $M$. gelatinosus was also rare, $H$. helianthus size did not vary significantly with depth $(p=0.68)$, although small individuals tended to be more common at greater depths (Fig. 3).

An additional survey at Flamenco in 2006 showed that the distribution of Heliaster helianthus was even more restricted than in the initial surveys in 2004 and 2005, as it had disappeared at $3 \mathrm{~m}$ depth. At the same time the density of Meyenaster gelatinosus had more than doubled (to 1.4 ind. $\mathrm{m}^{-2}$ ) at $3 \mathrm{~m}$ depth. Observations during a dive at Bahía Cisnes in March 2007 also showed a marked change in the abundance of $H$. helianthus: it occurred only in low numbers in the rocky 
Table 1. Results of 2-way ANOVAs testing for differences in the density of the 2 sea star species with Depth at each study location

\begin{tabular}{|lrcc|}
\hline Source & df & \multicolumn{1}{c|}{$F$} & $\mathrm{p}$ \\
\hline Flamenco & & & \\
$\quad$ Sea star & 1 & 1.05 & 0.31 \\
Depth & 4 & 11.07 & $<0.0001$ \\
Sea star $\times$ Depth & 4 & 7.54 & $<0.0001$ \\
Error & 427 & & \\
Ramada & & & \\
Sea star & 1 & 1.05 & 0.65 \\
Depth & 3 & 11.07 & 0.038 \\
Sea star $\times$ Depth & 3 & 7.54 & 0.0004 \\
Error & 244 & & \\
Bahía Cisnes & & & \\
Sea star & 1 & 117.06 & $<0.0001$ \\
Depth & 5 & 13.15 & $<0.0001$ \\
Sea star $\times$ Depth & 5 & 15.36 & $<0.0001$ \\
Error & 390 & & \\
Obispito & & & \\
$\quad$ Sea star & 1 & 50.02 & $<0.0001$ \\
Depth & 4 & 4.44 & 0.0018 \\
Sea star $\times$ Depth & 4 & 4.65 & 0.0013 \\
Error & 212 & & \\
& & & \\
\hline
\end{tabular}

High M. gelatinosus abundance

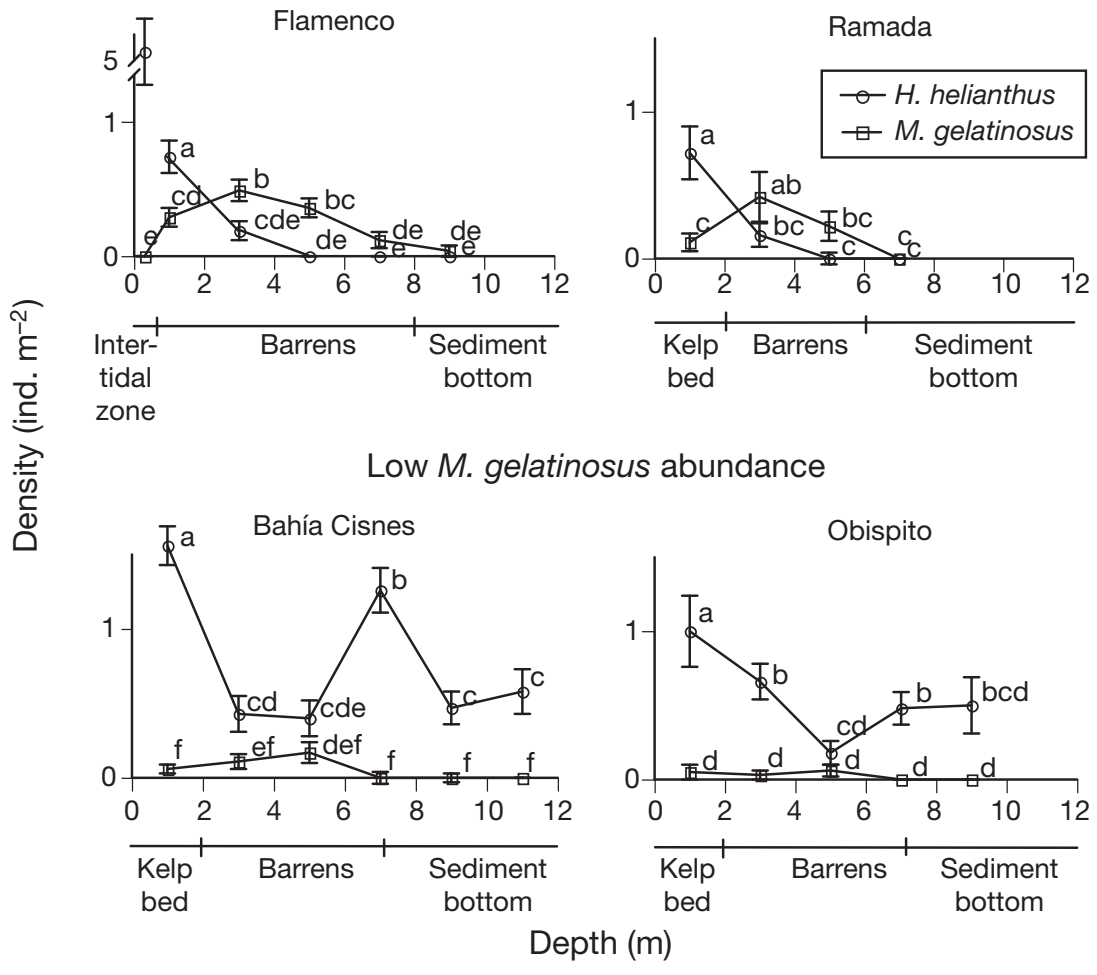

Fig. 2. Heliaster helianthus and Meyenaster gelatinosus. Abundance in relation to depth at 4 locations, 2 with high and 2 with low abundance of M. gelatinosus. Error bars represent \pm SE. For each species, values not sharing the same letters are significantly different zone and was absent in the sediment bottom zone. At the same time $M$. gelatinosus was more common throughout the rocky bottom zone.

\section{Occurrence of Heliaster helianthus with autotomized arms}

At Flamenco, the proportion of Heliaster helianthus with autotomized arms increased from $30 \%$ in the intertidal zone to $\sim 60 \%$ in the upper subtidal zone (Fig. 4). At Ramada, the proportion of individuals with autotomized arms was already $\sim 65 \%$ at 0 to $2 \mathrm{~m}$ depth and increased to $\sim 90 \%$ at 2 to $6 \mathrm{~m}$. In contrast, the proportion of $H$. helianthus with autotomized arms was low throughout the subtidal zone at Bahía Cisnes (22 to $29 \%$ ) and even lower across the subtidal zone at Obispito (5 to $15 \%$ ). A correlation analysis applied to the different depths and sites showed that the proportion of $H$. helianthus with autotomized arms was strongly correlated with the abundance of Meyenaster gelatinosus $\left(\mathrm{r}_{\mathrm{S}}=0.72, \mathrm{p}=0.012\right)$.

\section{Feeding of Heliaster helianthus and Meyenaster gelatinosus}

The percentage of Heliaster helianthus feeding was generally low at the 2 sites where Meyenaster gelatinosus was common. At Flamenco, although $56 \%$ of individuals fed in the upper subtidal zone $(0$ to $3 \mathrm{~m})$, none fed at greater depths. The main prey consumed in shallow water were the mussel Semimytilus algosus (54\%) and barnacles (17\%). At Ramada, only 33 to $35 \%$ of the individuals fed across the subtidal zone (Fig. 4) and the main prey were the mussel $S$. algosus $(21 \%)$ and the turban snail Tegula spp. (34\%). In contrast, the percentage of $H$. helianthus feeding increased with depth at the locations where there were few M. gelatinosus. At Bahía Cisnes, it increased from 38\% in the upper subtidal zone (0 to $2 \mathrm{~m}$ ) to $92 \%$ in the sediment zone, and at Obispito from 37 to $89 \%$ over the same depth range. In the upper subtidal zone, the urchin Tetrapygus niger was the main prey at Bahía Cisnes (57\%) and the mussel $S$. algosus at Obispito (38\%). In the sediment zone, the gastropod Turritella cingulata was the main prey at both sites (93 and 86\%, respectively). A correla- 


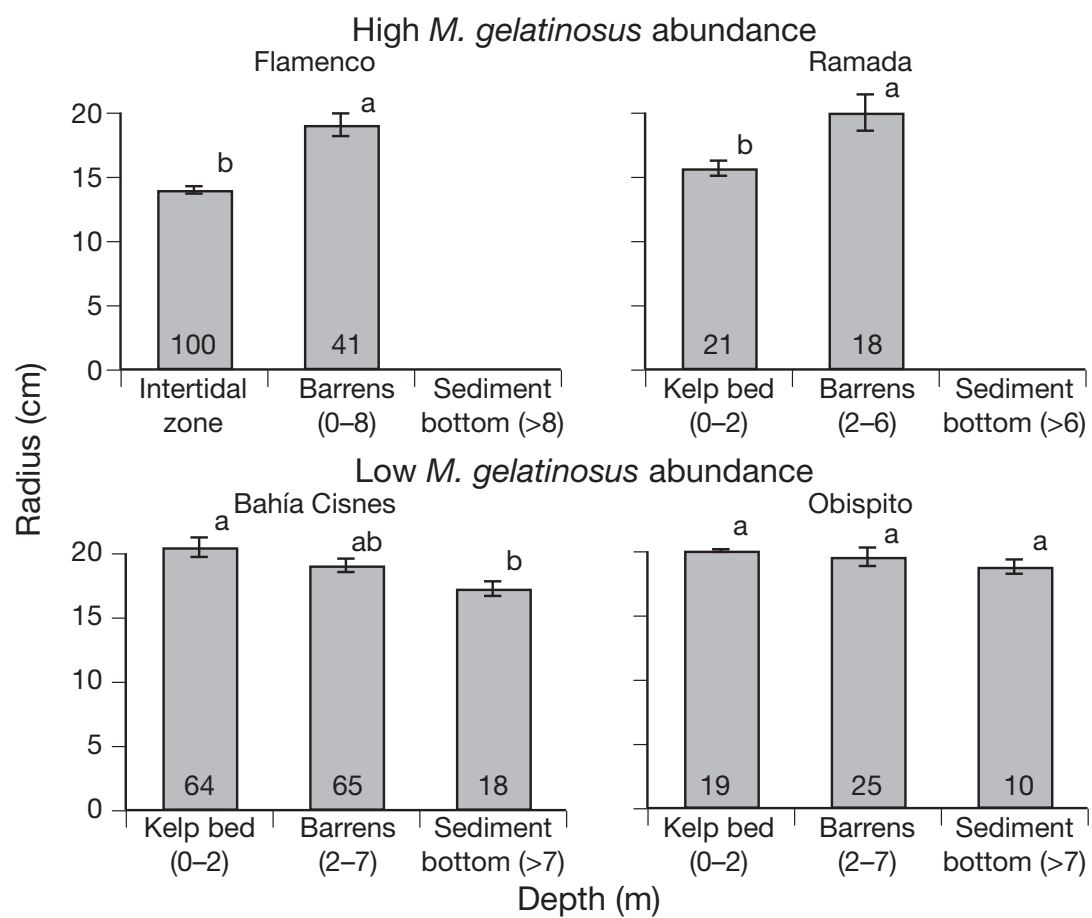

Fig. 3. Heliaster helianthus and Meyenaster gelatinosus. Average size of $H$. helianthus in different subtidal zones at locations with high and low abundance of M. gelatinosus. Sample size is indicated within the bar for each zone. Error bars represent \pm SE. Values not sharing the same letters are significantly different

High M. gelatinosus abundance

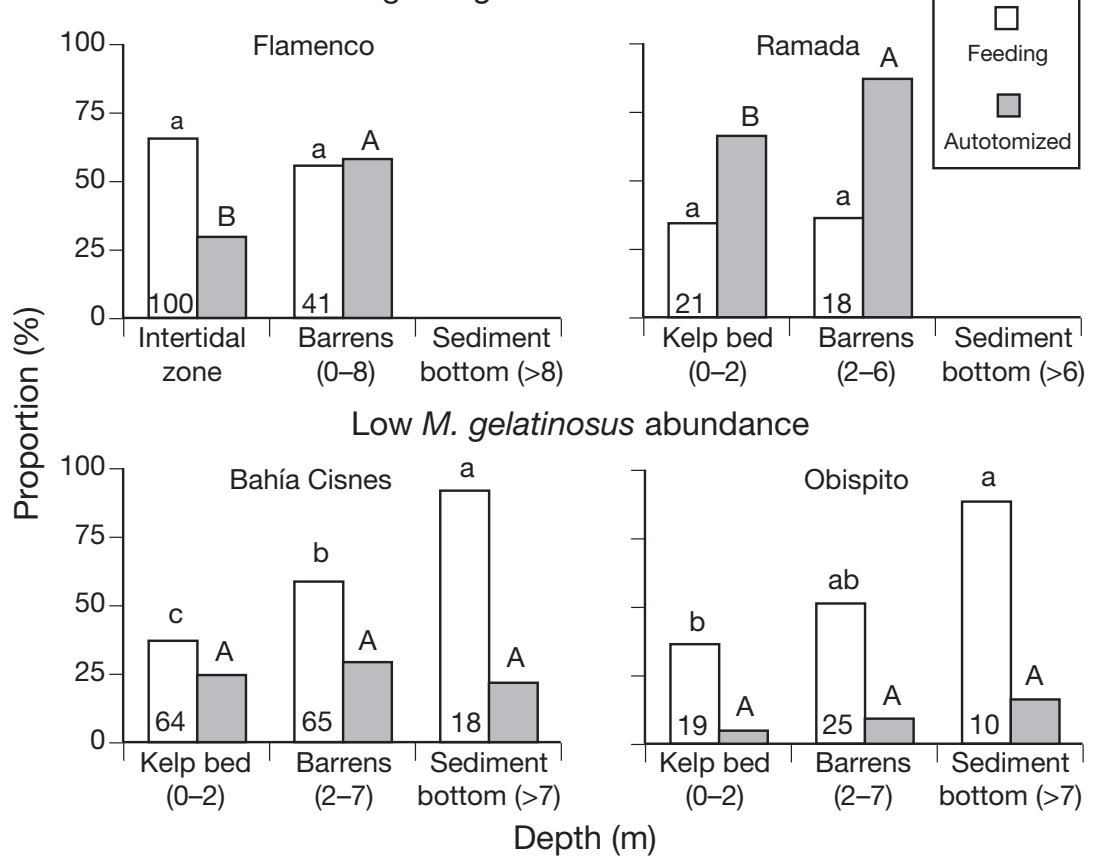

Fig. 4. Heliaster helianthus and Meyenaster gelatinosus. Proportion of H. helianthus feeding (white bars) and showing arm autotomy (grey bars) in different subtidal zones at locations with high and low abundance of $M$. gelatinosus. Sample size is indicated within the white bar for each zone. Values not sharing the same letters are significantly different tion analysis applied to the different depths and locations showed that the proportion of $H$. helianthus feeding was negatively correlated with the abundance of $M$. gelatinosus $\left(\mathrm{r}_{\mathrm{S}}=-0.60, \mathrm{p}=\right.$ 0.049).

The main prey items consumed by Meyenaster gelatinosus were the sea urchin Tetrapygus niger $30 \%$ of the prey items observed at the 4 locations) and Heliaster helianthus (22\% for the 4 locations together, but 39 to $42 \%$ at Bahía Cisnes and Ramada). Yule's $V$ selectivity index showed that both prey were selected by $M$. gelatinosus (Table 2). The frequency of the sea urchin in the diet of M. gelatinosus varied with its availability. At Flamenco and Ramada, where M. gelatinosus was common, both the density of the sea urchin (6.3 and $0.1 \mathrm{~m}^{-2}$, respectively) and its frequency in the diet of $M$. gelatinosus were low (8 and 18\%, respectively). In contrast, at Bahía Cisnes and Obispito, where there were few $M$. gelatinosus, both the density of the urchins (20 ind. $\mathrm{m}^{-2}$ at both locations) and their frequency in M. gelatinosus' diet were increased (27 and $65 \%$, respectively).

\section{Effect of Meyenaster gelatinosus on the behavior of Heliaster helianthus in the field}

Heliaster helianthus responded in a characteristic way to make contact with Meyenaster gelatinosus (Table 3). About $22 \mathrm{~s}$ after the initial contact, the arms that were touched began to move. Then at about $40 \mathrm{~s}$, all arm tips were raised so that the body resembled a crown (Fig. 1). At this point the tube feet did not appear to be attached to the bottom. After about $69 \mathrm{~s}$, the H. helianthus began to move away from $M$. gelatinosus. The mean time for separation from $M$. gelatinosus was slightly more than 2 min.

The Meyenaster gelatinosus that were added to the center of our $7 \mathrm{~m}^{2}$ circular experimental plots generally moved in straight lines, but in no specific direction, out of the plots. This resulted 
Table 2. Heliaster helianthus and Meyenaster gelatinosus. Yule's V prey selectivity index for different depth zones at Flamenco and Bahía Cisnes. ${ }^{* *} \mathrm{p}<0.01$; ${ }^{*} \mathrm{p}<0.05$; na: not available

\begin{tabular}{|c|c|c|c|c|c|}
\hline \multirow[t]{2}{*}{ Prey } & \multicolumn{2}{|c|}{$\begin{array}{c}\text { Flamenco- } \\
\text { Depth }(\mathrm{m})\end{array}$} & \multicolumn{3}{|c|}{$\begin{array}{c}\text { - Bahía Cisnes } \\
\text { Depth (m) }\end{array}$} \\
\hline & $<3$ & $3-6$ & $<2$ & $2-7$ & $>7$ \\
\hline \multicolumn{6}{|l|}{ H. helianthus } \\
\hline Tetrapygus niger & -0.007 & -0.000 & -0.266 & 0.016 & na \\
\hline Barnacles & $-0.042^{* *}$ & -0.001 & -0.022 & -0.004 & na \\
\hline Semimytilus algosus & $0.045^{* *}$ & -0.000 & $0.508^{* *}$ & na & na \\
\hline Tegula spp. & -0.007 & -0.009 & na & -0.008 & na \\
\hline Pyura chilensis & -0.011 & -0.001 & -0.055 & -0.010 & -0.000 \\
\hline Turritella cingulata & na & -0.002 & $0.190^{* *}$ & 0.002 & 0.000 \\
\hline Calyptrea trochiformis & na & $0.177^{* *}$ & na & na & na \\
\hline Fissurella spp. & -0.003 & -0.000 & -0.022 & na & na \\
\hline \multicolumn{6}{|l|}{ M. gelatinosus } \\
\hline Tetrapygus niger & $0.254^{* *}$ & $0.364^{* *}$ & $-0.303^{* *}$ & $0.151^{* *}$ & * na \\
\hline Barnacles & -0.016 & 0.003 & -0.033 & -0.002 & na \\
\hline Semimytilus algosus & $-0.072^{* *}$ & $-0.028^{* *}$ & na & na & na \\
\hline Tegula spp. & -0.004 & -0.000 & na & -0.003 & na \\
\hline Pyura chilensis & -0.004 & -0.000 & -0.023 & -0.004 & na \\
\hline Turritella cingulata & na & -0.001 & na & $-0.138^{* *}$ & na \\
\hline Calyptrea trochiformis & $0.242^{* *}$ & na & $0.497^{* *}$ & na & na \\
\hline Fissurella spp. & $0.148^{* *}$ & $0.067^{* *}$ & -0.009 & na & na \\
\hline Heliaster helianthus & $0.235^{* *}$ & $0.302^{* *}$ & $0.202^{* *}$ & $0.276^{* *}$ & na \\
\hline
\end{tabular}

in random contacts with Heliaster helianthus. All contacts ultimately led to the fleeing of $H$. helianthus, leaving the experimental area in the direction opposite to that of the initial contact with M. gelatinosus. At times when a fleeing $H$. helianthus came into contact with conspecifics, it triggered an escape response in others, causing a localized stampede. This was not seen when a moving $H$. helianthus that was not fleeing $M$. gelatinosus came into contact with conspecifics. After $80 \mathrm{~min}$ in our trials in the circular plots, $96 \%$ of $H$. helianthus had fled the plots where $M$. gelatinosus had been added, which compared with only $4 \%$ in the plots where no $M$. gelatinosus had been added (Table 4, Fig. 5).

Prior to the Meyenaster gelatinosus additions to the circular plots, $\sim 90 \%$ of the Heliaster helianthus were feeding (Fig. 6). The proportion dropped to $\sim 40 \%$ in plots where $M$. gelatinosus was added, but did not change in the plots where no M. gelatinosus were added.
Table 3. Heliaster helianthus in response to contact with Meyenaster gelatinosus $(\mathrm{n}=43)$

\begin{tabular}{|lcr|}
\hline & Average time (s) & \multicolumn{1}{c|}{ SE } \\
\hline First response & 21.6 & 3.3 \\
Crown position (all arms raised) & 39.7 & 6.1 \\
Beginning to move away & 68.7 & 10.6 \\
Separated from M. gelatinosus & 133.9 & 23.3 \\
\hline
\end{tabular}

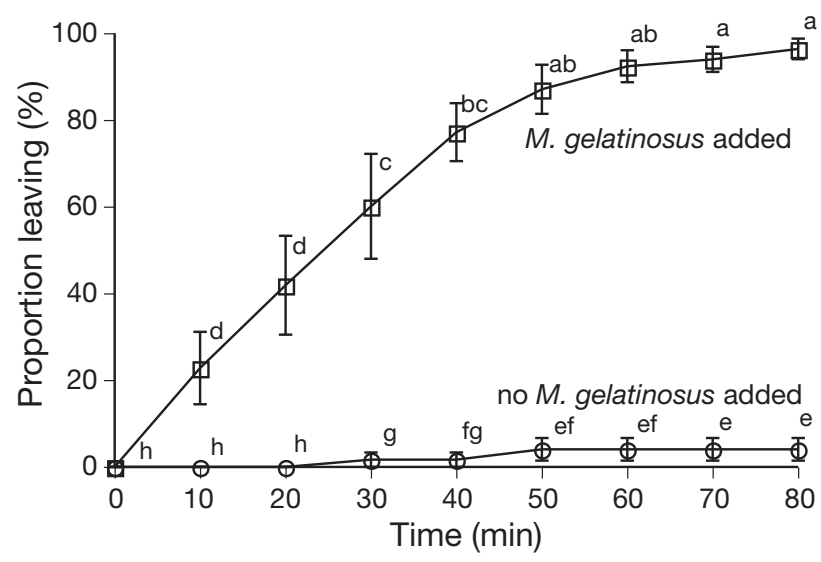

Fig. 5. Heliaster helianthus and Meyenaster gelatinosus. Proportion of $H$. helianthus leaving $3 \mathrm{~m}$ diameter circular plots in which we either added or did not add M. gelatinosus. Error bars represent \pm SE. Values not sharing the same letters are significantly different
Table 4. Results of a 2-way ANOVA testing for differences between control and Meyenaster gelatinosus addition areas (Treatment) in the proportion of Heliaster helianthus that left the circular areas at different times (Time)

\begin{tabular}{|lrrc|}
\hline Source & df & \multicolumn{1}{c|}{$F$} & \multicolumn{1}{c|}{$\mathrm{p}$} \\
\hline Treatment & 1 & 369.60 & $<0.0001$ \\
Time & 7 & 9.84 & $<0.0001$ \\
Treatment $\times$ Time & 7 & 6.67 & $<0.0001$ \\
Error & 88 & & \\
\hline
\end{tabular}

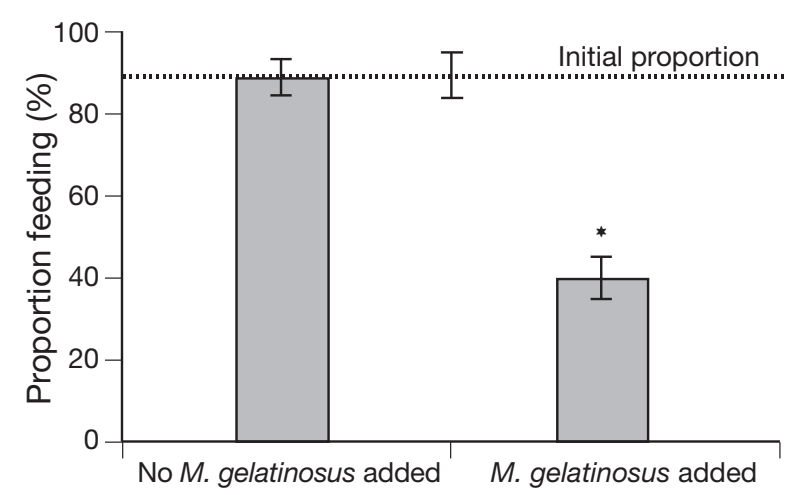

Fig. 6. Heliaster helianthus and Meyenaster gelatinosus. Initial proportion of $H$. helianthus feeding in circular experimental areas (dashed line) compared to the proportion feeding in areas where we added or did not add $M$. gelatinosus (bars). ${ }^{*}$ Significant difference between the treatment and the initial proportion feeding $(p<0.05)$. Error bars represent \pm SE 


\section{DISCUSSION}

Our study provides several lines of evidence indicating a strong predatory impact of Meyenaster gelatinosus on Heliaster helianthus. First, $H$. helianthus was commonly eaten by M. gelatinosus, and Yule's $V$ selectivity index indicated that $M$. gelatinosus selects $H$. helianthus. The high frequency of $H$. helianthus in the diet of $M$. gelatinosus was surprising because it is a large and very mobile prey. Second, our field surveys show an inverse relationship in the abundance of the 2 sea stars. At sites with low M. gelatinosus densities, $H$. helianthus occurred across the rocky subtidal zone and also into the sediment zone, whereas at sites with high $M$. gelatinosus densities, $H$. helianthus was only found in the intertidal and upper subtidal zones (Fig. 7). Nevertheless, we did not detect a small-scale segregation of the 2 sea stars (in the analysis of $1 \mathrm{~m}^{2}$ sampling quadrats), as reported between 2 competing subtidal sea stars Leptasterias polaris and Asterias vulgaris in the northern Gulf of St. Lawrence (Gaymer et al. 2001). It is unlikely that avoidance at the scale of $1 \mathrm{~m}^{-1}$ would reduce predatory attacks by $M$. gelatinosus, given that M. gelatinosus moves rapidly (up to $1.8 \mathrm{~cm} \mathrm{~s}^{-1}$; Viviani 1978) and can probably detect prey from a distance (as

High M. gelatinosus abundance

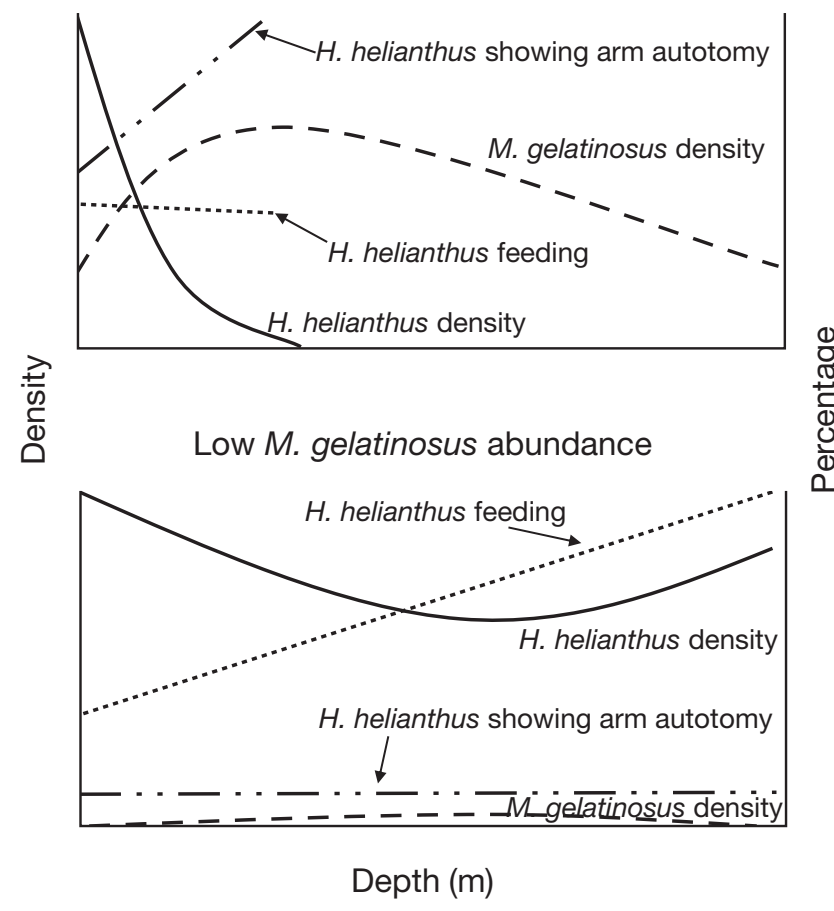

Fig. 7. Heliaster helianthus and Meyenaster gelatinosus. Generalized scheme of the depth distribution, and percentage of individuals feeding and showing arm loss (autotomy), for $H$. helianthus at locations with high and low abundance of M. gelatinosus documented for numerous sea stars; Sloan \& Aldridge 1981, Rochette et al. 1994, Drolet \& Himmelman 2004). The third index of the predatory impact of $M$. gelatinosus on $H$. helianthus was provided by the frequency of $H$. helianthus with autotomized arms (as reported for the sea stars Marthasterias glacialis and A. rubens; Ramsay et al. 2000). These mainly result from attacks by M. gelatinosus (Viviani 1978). The frequency of $H$. helianthus with autotomized arms was lower (5 to $29 \%$ ) across the rocky subtidal zone at locations with few $M$. gelatinosus, whereas it was higher and increased with depth at locations where $M$. gelatinosus was common (Fig. 7). The fourth observation indicating a predatory impact of M. gelatinosus was that the proportion of $H$. helianthus feeding was negatively related to the abundance of $M$. gelatinosus. At sites with few $M$. gelatinosus, the proportion of $H$. helianthus feeding increased with increasing depth (in part related to greater prey availability with increasing depth), whereas at sites where M. gelatinosus was common, the proportion was low and did not vary with depth (Fig. 7).

Our field experiments demonstrated a strong and unique escape response of Heliaster helianthus when touched by Meyenaster gelatinosus. H. helianthus took the 'crown' position, which involved raising the arm tips and detaching from the substratum (this occurred about $40 \mathrm{~s}$ after the initial contact), and then fleeing. The average time taken by $H$. helianthus to become separated from the predator was $2 \mathrm{~min}$. The sudden raising of the arms could serve to detach $H$. helianthus from a pursuing M. gelatinosus. Also, we observed that when there was strong wave action a $H$. helianthus in crown position could be carried away from its predator. Similarly, Dayton et al. (1977) reported that urchins Tetrapygus niger fleeing from sea star predators are less well attached and can be carried away by wave action. We noted that when a fleeing $H$. helianthus touched conspecifics, there appeared to be communication between the first individual touched and the others, causing a stampede away from the predator. This possibly involves an alarm signal, such as that employed by some gastropods (Yamada et al. 1998) and sea urchins (Hagen et al. 2002) when threatened by their predators.

Attacks by Meyenaster gelatinosus are often nonlethal. Nevertheless, sublethal predation (i.e. loss of arms) could have a considerable impact, as it may lead to decreases in mobility and feeding, and consequently reduced energy storage and growth (Lawrence \& Vásquez 1996, Díaz-Guisado et al. 2006, Naya \& Bozinovic 2006). Although sublethal predation clearly leads to decreased fitness in many species (see Maginnis 2006), it is rarely incorporated into predator-prey models (for an exception see Zajac 1995). Rather, most 
studies evaluate the effect of autotomy on the individual or population, but not on species interactions involving the autotomized species (see Maginnis 2006). The present study suggests that sublethal predation on Heliaster helianthus alters the role of this species in structuring the community. Recent studies in rocky intertidal communities in the Gulf of Maine indicate that the roles of the grazing snail Littorina littorea and the predatory snail Nucella lapillus are greatly reduced when these snails are exposed to the odor of a major predator, the green crab Carcinus maenas (Trussell et al. 2003, 2004). These sublethal effects, named trait-mediated indirect interactions, are passed on through a trophic cascade and result in an increased abundance of algae and prey species (Trussell et al. 2006).

Our observations indicate that Meyenaster gelatinosus can limit Heliaster helianthus' access to the extremely abundant prey Turritella cingulata. This gastropod covered the sediment bottom at Bahía Cisnes at a density of $\sim 3000$ ind. $\mathrm{m}^{-2}$ in 2003 . Individuals were piled on top of one another to a depth of 5 to $10 \mathrm{~cm}$ (Fig. 2). Laboratory trials (C. F. Gaymer unpubl. data) showed that $H$. helianthus can consume 3 averagesized ( $\sim 3 \mathrm{~cm}$ in length, or $1 \mathrm{~g}$ in tissue mass) $T$. cingulata $\mathrm{d}^{-1}$. At this rate, the $1.3 \mathrm{H}$. helianthus $\mathrm{m}^{-2}$ observed at Bahía Cisnes in 2003 could consume 4 T. cingulata $\mathrm{m}^{-2}$ $\mathrm{d}^{-1}\left(\sim 1460 \mathrm{~g} \mathrm{~m}^{-2} \mathrm{yr}^{-1}\right.$, equivalent to $49 \%$ of the standing crop in a year). Although many factors affect feeding rates (e.g. laboratory vs. field conditions, season), a high impact is also indicated by the high proportion of dead T. cingulata (42\%) observed when we returned to Bahía Cisnes in 2006. The deeper environment where $T$. cingulata is found should allow almost continuous feeding by $H$. helianthus, in contrast to shallow habitats, where sea star feeding is likely reduced by wave activity (Sousa 2001, Gagnon et al. 2003).

Whereas both Heliaster helianthus and Meyenaster gelatinosus are adapted to living throughout the rocky subtidal zone, our observations indicate that $H$. helianthus is often restricted to shallow depths because of the predatory impact of M. gelatinosus. Many benthic species are similarly limited to shallow depths because of consumer pressure, notably benthic macrophytes by sea urchins (Lawrence 1975, Himmelman et al. 1983) and mussels by sea stars (Gaymer et al. 2001, Gaymer \& Himmelman 2002). Smaller H. helianthus appear to be limited to even shallower depths (including the intertidal zone), probably because they are even more vulnerable to attacks by $M$. gelatinosus (they are likely slower at fleeing and more easily completely consumed because of their small size). H. helianthus recruits at shallow depths (Viviani 1978), which may represent an adaptation to avoid the predation threat of M. gelatinosus.
Studies are required to evaluate the roles of Heliaster helianthus and Meyenaster gelatinosus in determining the structure of subtidal communities in Chile. Paine et al. (1985) described $H$. helianthus as a keystone predator in intertidal communities in central Chile. The high numbers of this generalist predator at shallow depths suggests that its feeding could similarly have a strong impact on upper subtidal prey species, such as turban snails Tegula spp., keyhole limpets Fissurella spp. and barnacles. $H$. helianthus also preys on the whelk Concholepas concholepas (called the 'loco' in Chile), which Castilla \& Duran (1985) described as another keystone predator in intertidal communities. Thus, H. helianthus may also have a strong impact throughout the rocky subtidal zone, and even into the sediment zone, at locations where there are few $M$. gelatinosus. As the 'loco' is overexploited in most rocky communities in Chile, except in a few areas where humans are excluded, $H$. helianthus is left as the only recognized keystone intertidal predator (Navarrete \& Castilla 2003). However, the 'loco' populations should increase if the newly created marine protected areas (MPAs) along the coast of northern and central Chile succeed in preventing them from being harvested.

The predatory impact of Heliaster helianthus is undoubtedly greatly reduced in communities where Meyenaster gelatinosus is common or abundant. $M$. gelatinosus also presents a predatory risk for the 'loco' Concholepas concholepas, which responds with both an escape response and reduced feeding (Serra et al. 1997). Thus, it is more likely that $M$. gelatinosus, rather than $H$. helianthus or C. concholepas, is the keystone predator in Chilean rocky subtidal communities. In present-day communities in Chile, M. gelatinosus may be at the top of a trophic cascade (sensu Estes et al. 1998). The situation may have been different at an earlier time, as the impact of a number of large predatory fishes has been reduced by overfishing. These include Graus nigra and Primelometopon maculates, which are known to prey on sea stars (Fuentes 1982). Studies are needed to quantify the role of $M$. gelatinosus in structuring subtidal communities, for example by following manipulations of its numbers. Most rocky surfaces, in both areas with high and low M. gelatinosus densities, are covered by barrens with extensive cover by crustose coralline algae but few fleshy macrophytes. The most conspicuous grazer, the black sea urchin Tetrapygus niger, is a major prey of both $M$. gelatinosus and $H$. helianthus. However, as $H$. helianthus is a generalist predator, whereas $M$. gelatinosus prefers echinoderms (Aburto 1999 and Table 2), one might predict that a shift from $H$. helianthus to $M$. gelatinosus would lead to a reduction in urchin numbers and impact. A negative impact of $M$. gelatinosus on urchins was also suggested by our field data for locations with high and low 
M. gelatinosus abundance. In the upper sediment zone, we expect that high densities of Turritella cingulata can only develop when $H$. helianthus is excluded by $M$. gelatinosus. $M$. gelatinosus virtually does not feed on T. cingulata. In turn, high densities of T. cingulata likely limit numbers of infaunal and epifaunal species. We predict that the recent disappearance of $H$. helianthus from the sediment zone at Bahía Cisnes (in 2007) will now allow T. cingulata numbers to increase.

It is likely that numbers of Meyenaster gelatinosus and Heliaster helianthus are not specific to particular sites but change over time. We detected changes within 2 yr at both Bahía Cisnes and Flamenco. Shifts are probably first caused by a change in the numbers of $M$. gelatinosus, which consequently changes the numbers of $H$. helianthus. We have a poor understanding of the factors controlling the distribution of $M$. gelatinosus. Its morphology (Fig. 1) would suggest that it is poorly adapted to withstanding the strong wave action often characteristic of shallow subtidal areas. For example, its large size (up to $50 \mathrm{~cm}$ ) and relatively thick arms likely create resistance to waves. In contrast, $H$. helianthus, even though it can be large (up to $32 \mathrm{~cm}$ ), is thinner (Fig. 1) and more closely adheres to rocky surfaces, thus reducing resistance to water movement. Its many arms and large numbers of podia should also enhance attachment. Finally, its body wall is more robust than that of $M$. gelatinosus (which is soft), so that it should be less vulnerable to damage from moving objects. Studies are needed to elucidate factors causing changes in M. gelatinosus populations over time.

Certain predators may be 'keystones' in specific habitats, but their role may change in other habitats, even adjacent habitats (Power et al. 1996), and this seems to be the case for Heliaster helianthus. We have documented that the predatory role of $H$. helianthus in rocky coastal communities in Chile can be greatly reduced in the rocky subtidal zone by a higher-order predator, Meyenaster gelatinosus, which limits its numbers, foraging activities and access to prey.

Acknowledgements. We are grateful to J. Barrios and A. Vega for their help in sampling in the field. C. P. Dumont, M. Thiel and P. S. Petraitis made useful suggestions for improving the paper. The study was supported by a Fondo Nacional de Desarrollo Científico y Tecnológico (FONDECYT, Chile) grant (\#3030007) to C.F.G.

\section{LITERATURE CITED}

Abrams PA, Menge BA, Mittlebach GG, Spiller D, Yodzis P (1996) The role of indirect effects in food webs. In: Polis G, Winemiller K (eds) Food webs: dynamics and structure. Chapman \& Hall, New York, p 371-395

Aburto JA (1999) Estructura poblacional, abundancia y dieta de Meyenaster gelatinosus (Meyen, 1834) (Equinodermata: Asteroidea) en distintas comunidades del submareal rocoso somero en la región de Coquimbo. Honors thesis, Universidad Católica del Norte, Coquimbo

Castilla JC, Duran LR (1985) Human exclusion from the rocky intertidal zone of central Chile: the effects on Concholepas concholepas (Gastropoda). Oikos 45:391-399

Conover WJ (1980) Practical nonparametric statistics. John Wiley \& Sons, New York

Dahl J, Peckarsky BL (2003) Developmental responses to predation risk in morphologically defended mayflies. Oecologia 137:188-194

Dayton PK, Rosenthal RJ, Mahen LC, Antezana T (1977) Population structure and foraging biology of the predaceous Chilean asteroid Meyenaster gelatinosus and the escape biology of its prey. Mar Biol 39:361-370

Díaz-Guisado D, Gaymer CF, Brokordt KB, Lawrence JM (2006) Autotomy reduces feeding, energy storage and growth of the sea star Stichaster striatus. J Exp Mar Biol Ecol 338:73-80

> Drolet D, Himmelman JH (2004) Role of current and prey odour in the displacement behaviour of the sea star Asterias vulgaris. Can J Zool 82:1547-1553

Esser M, Greve W, Boersma M (2004) Effects of temperature and the presence of benthic predators on the vertical distribution of the ctenophore Pleurobrachia pileus. Mar Biol 145:595-601

Estes JA, Tinker MT, Williams TM, Doak DF (1998) Killer whale predation on sea otters linking oceanic and nearshore ecosystems. Science 282:473-476

Fuentes HR (1982) Feeding habits of Graus nigra (Labridae) in coastal waters of Iquique in northern Chile. Jpn J Ichthyol 29:95-98

> Gagnon P, Wagner G, Himmelman JH (2003) Use of a wave tank to study the effects of water motion and algal movement on the displacement of the sea star Asterias vulgaris towards its prey. Mar Ecol Prog Ser 258:125-132

Gaymer CF, Himmelman JH (2002) Mussel beds in deeper water provide an unusual situation for competitive interactions between the sea stars Leptasterias polaris and Asterias vulgaris. J Exp Mar Biol Ecol 277:13-24

Gaymer CF, Himmelman JH, Johnson LE (2001) Distribution and feeding ecology of the seastars Leptasterias polaris and Asterias vulgaris in the northern Gulf of St. Lawrence, Canada. J Mar Biol Assoc UK 81:827-843

Hagen NT, Andersen A, Stabell OB (2002) Alarm responses of the green sea urchin, Strongylocentrotus droebachiensis, induced by chemically labelled durophagous predators and simulated acts of predation. Mar Biol 140:365-374

$>$ Himmelman JH, Cardinal A, Bourget E (1983) Community development following removal of urchins, Strongylocentrotus droebachiensis, from the rocky subtidal zone of the St. Lawrence Estuary, eastern Canada. Oecologia 59:27-39

Kendall MG (1947) The advanced theory of statistics. Charles Griffin \& Company, London

Lawrence JM (1975) On the relationships between marine plants and sea urchins. Oceanogr Mar Biol Annu Rev 13: 213-286

Lawrence JM, Vásquez J (1996) The effect of sublethal predation on the biology of echinoderms. Oceanol Acta 19: $431-440$

Lima SL, Dill LM (1990) Behavioral decisions made under the risk of predation: a review and prospectus. Can J Zool 68: $619-640$

Littell RC, Milikan GA, Stroup WW, Wolfinger RD (1996) SAS system for mixed models. SAS Institute, Cary, NC

Maginnis TL (2006) The cost of autotomy and regeneration 
in animals: a review and framework for future research. Behav Ecol 17:857-872

McCullagh P, Nelder GA (1989) Generalized linear model. Chapman \& Hall, London

Menge BA, Berlow EL, Blanchette CA, Navarrete SA, Yamada SB (1994) The keystone species concept: variation in interaction strength in a rocky intertidal habitat. Ecol Monogr 64:249-286

Navarrete SA, Castilla JC (2003) Experimental determination of predation intensity in an intertidal predator guild: dominant versus subordinate prey. Oikos 100:251-262

Naya DE, Bozinovic F (2006) The role of ecological interactions on the physiological flexibility of lizards. Funct Ecol 20:601-608

Norberg J, Tedengren M (1995) Attack behaviour and predatory success of Asterias rubens L. related to differences in size and morphology of the prey mussel Mytilus edulis L. J Exp Mar Biol Ecol 186:207-220

Ortiz M, Jesse S, Stotz W, Wolff M (2003) Feeding behavior of the asteroid Meyenaster gelatinosus in response to changes in abundance of the scallop Argopecten purpuratus in northern Chile. Arch Hydrobiol 157:213-225

Paine RT (1974) Intertidal community structure: experimental studies on the relationship between a dominant competitor and its principal predator. Oecologia 15:93-120

Paine RT, Castilla JC, Cancino J (1985) Perturbation and recovery patterns of starfish-dominated intertidal assemblages in Chile, New Zealand, and Washington state. Am Nat 125: 679-691

Pearre S (1982) Estimating prey preference by predators: uses of various indices, and a proposal of another based on $\chi^{2}$. Can J Fish Aquat Sci 39:914-923

Power ME, Tilman D, Estes JA, Menge BA and others (1996) Challenges in the quest for keystones. Bioscience 46: 609-620

Ramsay K, Turner JR, Vize SJ, Richardson CA (2000) A link between predator density and arm loss in the starfish Marthasterias glacialis and Asterias rubens. J Mar Biol Assoc UK 80:565-566

Reimer O, Harms-Ringdahl S (2001) Predator-inducible changes in blue mussels from the predator-free Baltic Sea. Mar Biol 139:959-965

Reimer O, Olsson B, Tedengren M (1995) Growth, physiological rates and behaviour of Mytilus edulis exposed to the predator Asterias rubens. Mar Freshw Behav Physiol 25: 233-244

Rochette R, Dill LM (2000) Mortality, behavior and the effects of predators on the intertidal distribution of littorinid gastropods. J Exp Mar Biol Ecol 253:165-191

Rochette R, Hamel JF, Himmelman JH (1994) Foraging strat-

Editorial responsibility: Charles Peterson,

Morehead City, North Carolina, USA egy of the asteroid Leptasterias polaris: role of prey odors, current and feeding status. Mar Ecol Prog Ser 106: 93-100

SAS Institute (1991) SAS/STAT user's guide, release 6.03 edition. SAS Institute Press, Cary, NC

Serra G, Chelazzi G, Castilla JC (1997) Effects of experience and risk of predation on the foraging behaviour of the South-eastern Pacific muricid Concholepas concholepas (Mollusca: Gastropoda). J Anim Ecol 66:876-883

Sih A, Crowley P, McPeek M, Petranka J, Strohmeier K (1985) Predation, competition, and prey communities: a review of field experiments. Annu Rev Ecol Syst 16:269-311

Sloan NA, Aldridge TH (1981) Observations on an aggregation of the starfish Asterias rubens L. in Morecambe Bay, Lancashire, England. J Nat Hist 15:407-418

Snedecor GW, Cochran WG (1989) Statistical methods. Iowa State University Press, Ames, IA

Sousa WP (2001) Natural disturbance and the dynamics of marine benthic communities. In: Bertness MD, Gaines SD, Hay ME (eds) Marine community ecology. Sinauer Associates, Sunderland, MA, p 85-130

Steel R, Torrie J (1980) Principles and procedures of statistics, a biometrial approach. McGraw-Hill, New York

Trussell GC, Ewanchuk PJ, Bertness MD (2003) Trait-mediated effects in rocky intertidal food chains: predator risk cues alter prey feeding rates. Ecology 84:629-640

Trussell GC, Ewanchuk PJ, Bertness MD, Silliman BR (2004) Trophic cascades in rocky shore tide pools: distinguishing lethal and nonlethal effects. Oecologia 139:427-432

Trussell GC, Ewanchuk PJ, Matassa CM (2006) The fear of being eaten reduces energy transfer in a simple food chain. Ecology 87:2979-2984

Viviani CA (1978) Predación interespecífica, canibalismo y autotomía como mecanismo de escape en las especies de Asteroidea (Echinodermata) en el litoral del desierto del norte grande de Chile. Laboratorio de Ecología Marina, Universidad del Norte, Iquique

Wentworth CK (1922) A scale of grade and class terms for clastic sediments. J Geol 30:377-392

Yamada SB, Navarrete SA, Needham C (1998) Predation induced changes in behavior and growth rate in three populations of the intertidal snail, Littorina sitkana (Philippi). J Exp Mar Biol Ecol 220:213-226

Yunger JA (2004) Movement and spatial organization of small mammals following vertebrate predator exclusion. Oecologia 139:647-654

Zajac RN (1995) Sublethal predation on Polydora cornuta (Polychaeta, Spionidae), patterns of tissue loss in a field population, predator, functional-response and potential demographic impacts. Mar Biol 123:531-541

Submitted: November 19, 2007; Accepted: July 23, 2008 Proofs received from author(s): October 18, 2008 